Gut, 1984, 25, 1414-1415

Case report

\title{
Recurrent jaundice caused by recurrent hyperemesis gravidarum
}

\author{
D LARREY, B RUEFF, G FELDMANN, C DEGOTT, \\ G DANAN, AND J P BENHAMOU
}

From The Unité de Recherches de Physiopathologie Hépatique (INSERM), and The Service d'Anatomie et de Cytologie Pathologiques, Hôpital Beaujon, Clichy, France

SUMMARY The existence of jaundice induced by hyperemesis gravidarum is controversial. We report the case of a woman who suffered from three episodes of jaundice during the first trimester of three consecutive pregnancies, a few days after the onset of hyperemesis gravidarum. Jaundice was caused by conjugated hyperbilirubinaemia. Serum alanine aminotransferase activity was increased and scarce necrotic hepatocytes were shown on light and electron microscopic examinations. Cessation of vomiting was rapidly followed by complete recovery. This observation supports the view that severe vomiting can cause jaundice in pregnant women.

Hyperemesis gravidarum had long been a recognised cause of jaundice. ${ }^{1-6}$ Since 1960 , however, several authors have questioned the causal relationship between hyperemesis gravidarum and jaundice, and attributed jaundice affecting pregnant women with severe vomiting to chloroform, ${ }^{78}$ antiemetic drugs, ${ }^{9}$ or viral hepatitis. ${ }^{79}$ Hyperemesis gravidarum is mentioned as a cause of jaundice in some recent handbooks of hepatology, ${ }^{10}{ }^{11}$ but not in others. ${ }^{12-14}$ In this report, we describe the case of a woman in whom the development of jaundice was distinctly related to hyperemesis gravidarum: this patient suffered from three episodes of jaundice during the first trimester of three consecutive pregnancies, a few days after the onset of severe vomiting.

\section{Case report}

A 30 year old woman was admitted to Hôpital Beaujon on 28 May, 1981 with jaundice. In 1976, during her first pregnancy, she suffered from mild vomiting and was not jaundiced. In January 1979, at the fifth week of her second pregnancy, one week after the onset of hyperemesis gravidarum, jaundice developed; the liver size was normal; serum alanine

Address for correspondence: Dr D Larrey, INSERM U 24, Hôpital Beaujon. 92118 Clichy, France.

Received for publication 21 February 1984 aminotransferase was 22 times the upper limit of normal; serum bilirubin was $102 \mu \mathrm{mol} / \mathrm{l}$; vomiting stopped after parenteral administration of metoclopramide; jaundice then diminished rapidly; at the 18th week of pregnancy, serum alanine aminotransferase and serum bilirubin were normal. In December 1979, at the ninth week of her third pregnancy, six days after the onset of hyperemesis gravidarum, jaundice developed again; serum alanine aminotransferase was eight times the upper limit of normal; serum bilirubin was $78 \mu \mathrm{mol} / 1$; the liver and biliary tract were normal on ultrasonography; vomiting stopped after parenteral administration of metoclopramide; a normal diet was resumed and serum alanine aminotransferase and serum bilirubin returned to normal; spontaneous abortion occurred at the 15 th week. In May 1981, at the 10th week of her fourth pregnancy, six days after the onset of hyperemesis gravidarum, the patient was jaundiced again; serum alanine aminotransferase was five times the upper limit of normal; serum bilirubin was $58 \mu \mathrm{mol} / \mathrm{l}$. On $28 \mathrm{May}, 1981$ at the 12th week of pregnancy, the patient was admitted to Hôpital Beaujon for further investigations.

On admission, the patient complained of abundant vomiting; the weight loss was $11 \mathrm{~kg}$. She was jaundiced and the liver span was $8 \mathrm{~cm}$ on the right miclavicular line. Serum bilirubin was 100 $\mu \mathrm{mol} / \mathrm{l}$; serum conjugated bilirubin $85 \mu \mathrm{mol} / \mathrm{l}$; serum 
alanine aminotransferase seven times the upper limit of normal; serum alkaline phosphatase normal; prothrombin normal; HBsAg, anti-HBs, and anti$\mathrm{HBc}$ absent; anti-HA absent; red blood cell count $4200000 / \mathrm{mm} 3$; reticulocyte count $48000 / \mathrm{mm} 3$. Histologic examination of a liver specimen taken by percutaneous needle biopsy showed cholestasis and scarce necrotic hepatocytes in the centrilobular area. Oil red 0 staining on frozen section did not show any cytoplasmic fatty vacuoles. Electron microscopic examination showed deposits of pigments within the lumen of few canaliculi which were moderately dilated and had lost their microvilli; a few necrotic hepatocytes were seen. Intravenous administration of sulpiride was started on 29 May and was followed by cessation of vomiting on 31 May. Jaundice decreased rapidly and disappeared on 10 June. Serum bilirubin, serum alkaline phosphatase, and serum alanine aminotransferase were normal on 15 June. The patient gave birth to healthy twins in November.

\section{Discussion}

The development of jaundice one week after the onset of severe vomiting during the first trimester of three consecutive pregnancies and the rapid recovery after cessation of vomiting strongly suggest a causal relationship between hyperemesis gravidarum and icterus in our patient. This view is reinforced by the following arguments: (a) jaundice did not develop during our patient's first pregnancy which was not accompanied by severe vomiting; (b) our patient did not suffer from chronic liver disease; (c) drug hepatitis can be excluded: metoclopramide and sulpiride, the only two drugs which were given to our patient, were administered after the onset of jaundice; (d) jaundice because of obstruction of the common bile duct, in particular by biliary stone, is unlikely because of the absence of pain and normal ultrasonography; (e) recurrent cholestasis of pregnancy and acute fatty liver of pregnancy can be excluded: these conditions do not develop during the first trimester of pregnancy and are associated with manifestations and liver lesions ${ }^{15} 16$ different from those observed in our patient.

The mechanism of jaundice induced by hyperemesis gravidarum is obscure. Fasting reduces BSP elimination and slightly increases serum aminotransferases in obese patients. ${ }^{17}$ Fasting decreases bile flow and bile salt excretion in the rat. ${ }^{18}$ Kwashiorkor, a condition with prolonged denutrition, can be associated with hyperbilirubinaemia and increased serum aminotransferases. ${ }^{19}$ The view that fasting may contribute to jaundice because of hyperemesis gravidarum is consistent with the observation that, even in the absence of jaundice, BSP elimination is lower in women with hyperemesis gravidarum than in those with mild or without vomiting. ${ }^{20}$ Jaundice might be the major form of this usually subclinical hepatic dysfunction.

\section{References}

1 Herold L. Die leberfunktion in der physiologischen Schwangerschaft und bei der Hyperemesis gravidarum. Arch Gynaekol 1939; 168: 509-24.

2 Verhage JC. Hyperemesis gravidarum. Ned Tijdschr Verlosk Gynaecol 1940; 43: 36-74.

3 Millar D. The significance of jaundice in pregnancy. $J$ Obstet Gynaecol Br Emp 1954; 61: 405.

4 Thorling L. Jaundice in pregnancy. A clinical study. Acta Med Scand 1955; 151: suppl 302: 1-123.

5 Meyer J. Ikterus und Schwangerschaft. Geburtshilfe Fraunheilkd 1955; 15: 1013-19.

6 Klier E. Ikterus im Rahmen der Schwangershaftsfrühtoxikose. Wien Klin Wochenschr 1956; 68: 64-6.

7 Sheehan HL. Jaundice in pregnancy. Am J Obstet Gynecol 1961; 81: 427-40.

8 Klatskin G. Toxic and drug-induced hepatitis. In: Schiff L, ed. Diseases of the Liver 2nd ed. Philadelphia: Lippincott, 1963: 453-538.

9 Iber FL. Jaundice in pregnancy-a review. Am J Obstet Gynecol 1965; 91: 721-53.

10 Sherlock S. Diseases of the liver and biliary system. 6th ed. Oxford: Blackwell Scientific Publications, 1981: $400-5$

11 Krejs GJ, Haemmerli UP. Jaundice during pregnancy. In: Schiff L, ed. Diseases of the liver 5th ed. Philadelphia: Lippincott, 1982: 1561-80.

12 Sherlock S. Diseases of the Liver and Biliary System 5th ed. Oxford: Blackwell Scientific Publications, 1975: 570-8.

13 Schaffner F, Popper H. Classification and mechanism of cholestasis. In: Wright R, Alberti KGMM, Karran $\mathrm{S}$, Millward-Sadler GH, eds. Liver and Biliary Disease. Pathophysiology. Diagnosis. Management. London: Saunders, 1979: 296-323.

14 Benhamou JP. Foie et grossesse. In: Benhamou JP, Sarles H, Gerolami A, eds. Foie, Pancréas, Voies Biliaires. 3rd ed. Paris: Flammarion, 1980: 105-6.

15 Haemmerli UP. Jaundice during pregnancy with special emphasis on recurrent jaundice during pregnancy and its differential diagnosis. Acta Med Scand 1966; 179: suppl 444: 1-111.

16 Holzbach RT. Jaundice in pregnancy-1976. Am J Med 1976; 61: 367-76.

17 Verdy M. BSP retention during total fasting. Metabolism 1966; 15: 769-72.

18 Mahu JL, Duvaldestin P, Dhumeaux D, Berthelot P. Biliary transport of cholephilic dyes: evidence for two different pathways. Am J Physiol 1977; 232: E445-50.

19 Webber BL, Freiman I. The liver in Kwashiorkor. Arch Pathol 1974; 98: 400-8.

20 Adams RH, Gordon J, Combes B. Hyperemesis gravidarum. I. Evidence of hepatic dysfunction. Obstet Gynecol 1968; 31: 659-64. 